\title{
INCREASING POPULATION OF THE INVADER ROUND GOBY, NEOGOBIUS MELANOSTOMUS (ACTINOPTERYGII: PERCIFORMES: GOBIIDAE), AND ITS TROPHIC ROLE IN THE CURONIAN LAGOON, SE BALTIC SEA
}

\author{
Vytautas RAKAUSKAS ${ }^{1 *}$, Žilvinas PŪTYS ${ }^{2}$, Justas DAINYS ${ }^{2}$, Jūratė LESUTIENE ${ }^{3}$, \\ Linas LOŽYS ${ }^{2}$, and Kęstutis ARBAČIAUSKAS ${ }^{1,4}$
}

\author{
${ }^{1}$ Laboratory of Evolutionary Ecology of Hydrobionts, Nature Research Centre, Vilnius, Lithuania \\ ${ }^{2}$ Laboratory of Marine Ecology, Nature Research Centre, Vilnius, Lithuania \\ ${ }^{3}$ Coastal Research and Planning Institute, Klaipéda University, Klaipéda, Lithuania \\ ${ }^{4}$ Department of Zoology, Vilnius University, Vilnius, Lithuania
}

\begin{abstract}
Rakauskas V., Pūtys Ž., Dainys J., Lesutienė J., Ložys L., Arbačiauskas K. 2013. Increasing population of the invader round goby, Neogobius melanostomus (Actinopterygii: Perciformes: Gobiidae), and its trophic role in the Curonian Lagoon, SE Baltic Sea. Acta Ichthyol. Piscat. 43 (2): 95-108.
\end{abstract}

\begin{abstract}
Background. The round goby, Neogobius melanostomus (Pallas, 1814), is a recent invader in the Curonian Lagoon, SE Baltic Sea. As invasive species are among the most severe threats for biodiversity loss and can induce food web alterations, the development of round goby population in the Curonian Lagoon and its possible impacts on fish community and the entire ecosystem are of great scientific interest. This research reports on the expansion and trophic role of round goby in the Curonian Lagoon.

Materials and methods. Occurrence and abundance of round goby was investigated using a beach seine and gill nets at the northern and central parts of the Curonian Lagoon during a six-year period from 2007 to 2012. The trophic niche of the newcomer was revealed by applying gut content and stable isotope analyses (SIA). A total of 61 samples of other fish species were taken for SIA in order to reveal with which resident fish species the exploitative competition could be expected. Stable isotope mixing models were used to evaluate the contribution of round goby to the nutrition of top predators of the Curonian Lagoon: European perch, Perca fluviatilis Linnaeus, 1758; pike-perch, Sander lucioperca (Linnaeus, 1758); great cormorant, Phalacrocorax carbo; and grey heron, Ardea cinerea.

Results. The survey showed that round goby expanded its distribution area and recently occurs in the entire Lithuanian part of the Curonian Lagoon. Variation in the density of round goby suggests that the invader's abundance may be stabilised in the northern part of the lagoon. Gut content and stable isotope analyses showed round goby being mainly benthivorous. The largest trophic overlap with respect to SIA was detected between the invader and ruffe, Gymnocephalus cernua (Linnaeus, 1758), the fish which presumably exploits the same habitat type. According to stable isotope mixing models round goby was included with considerable shares into the diet of top predators.

Conclusion. The further expansion of round goby inside the Curonian Lagoon is ongoing. However, there is evidence on population density stabilisation in the northern part of the lagoon. Native benthivorous fish, especially ruffe, may be affected through competition for food resources in habitats where the newcomer is numerous. Round goby significantly contributes to the diet of piscivorous fish and birds. That may promote the regulation of invader population abundance in the lagoon.
\end{abstract}

Keywords: aquatic invasion, diet composition, stable isotopes

\section{INTRODUCTION}

Invasive species are one of the major threats for biodiversity loss through competitive and predatory impacts on resident species, as well as it is for ecosystem functioning through alterations in the food webs (Vander Zanden et al. 1999, Anonymous 2005). Contemporary conservation and resource management of aquatic ecosystems warrant assessment of the trophic role of the invading species in order to predict the impact they may have on native communities.

The round goby, Neogobius melanostomus (Pallas, 1814), originating from the Ponto-Caspian region, is a recent invader in the Baltic Sea and the Great Lakes (see Kornis et al. 2012 for review). Round goby invaded the Baltic

\footnotetext{
* Correspondence: Vytautas Rakauskas, hidrobiontų evoliucinès ekologijos laboratorija, Gamtos tyrimų centras, Akademijos g. 2, LT-08412 Vilnius-21, Lithuania, phone: +37 061-290-735, e-mail: vrakauskas@ekoi.lt.
} 
Sea, namely the Gulf of Gdańsk, in the 1990s (Skóra and Stolarski 1993). Then it spread northward along the Eastern Baltic Sea coast, reaching the Vistula Lagoon (Borowski 1999), the Curonian Lagoon (Bacevičius 2003, Zolubas 2003), Parnu Bay (NE part of the Gulf of Riga) (Shpilev and Ojaveer 2003), and Muuga Bay (at the southwestern coast of the Gulf of Finland) (Ojaveer 2006), in the Odra River estuary (Czugała and Woźniczka 2010), and waters of the Netherlands (Van Beek 2006).

The round goby was recorded in Lithuanian Baltic Sea coastal waters and the Curonian Lagoon for the first time in 2002 (Bacevičius 2003, Zolubas 2003). Soon, it formed a viable population in the northern part of the lagoon, influenced by the brackish sea water (Rakauskas et al. 2008). As this species is euryhaline, capable to survive in brackish and fresh water (Corkum et al. 2004, Kornis et al. 2012), it was predicted, that round goby would expand its population towards freshwater areas of the Curonian Lagoon (Rakauskas et al. 2008).

Round goby is a benthivorous, mainly molluscivorous fish in both native- (Svietovidov 1964, Kovtun et al. 1974, Bănaru and Harmelin-Vivien 2009) and invaded (Raby et al. 2010, Barton et al. 2005, Kipp et al. 2012) regions. It enhances the trophic pathway from molluscs to higher trophic levels becoming an important prey for top predators (Bzoma and Meissner 2005, Johnson and McCullough 2008, Almqvist et al. 2010, Bur et al. unpublished*). Round goby is also expected to compete for food with other molluscivores such as roach, Rutilus rutilus (Linnaeus, 1758), and freshwater bream, Abramis brama (Linnaeus, 1758). It has been documented that round goby and ruffe, Gymnocephalus cernua (Linnaeus, 1758), have the same habitat preferences (Bauer et al. 2007). Thus, feeding and habitat competition between these benthivorous fish species is highly possible. Other fish species at different life stages might also have dietary niche overlap with gobies, and round goby itself can undergo ontogenetic diet changes (Jude et al. 1995, Ray and Corkum 1997, French and Jude 2001, Lederer et al. 2006), which should be acknowledged while evaluating its trophic role in the ecosystem.

Analytical tools, such as stable carbon $\left({ }^{13} \mathrm{C} /{ }^{12} \mathrm{C}\right.$ or $\left.\delta^{13} \mathrm{C}\right)$ and nitrogen $\left({ }^{15} \mathrm{~N} /{ }^{14} \mathrm{~N}\right.$ or $\left.\delta^{15} \mathrm{~N}\right)$ isotope analysis may provide robust information on the trophic role of the species in an invaded food web (Vander Zanden et al. 1999). The ratio of carbon isotopes vary substantially among primary producers, but change little with trophic transfers, thus it is used to determine ultimate sources of dietary carbon in the consumer, while $\delta^{15} \mathrm{~N}$ values change from resource to consumer tissues is considerable and predictable and could be used to reconstruct the trophic position in the food chain (Post 2002). Consequently, dual isotope analysis can be used to describe the trophic niche of a certain consumer and its overlap with resident species (Layman et al. 2007, Schmidt et al. 2007).

The aims of this study were as follows:

- To assess the current trends (within 2007-2012) in distribution and abundance of round goby which has invaded the Curonian Lagoon in 2002;
- To explore the trophic niche of the invader by applying gut content and stable isotope (carbon ${ }^{13} \mathrm{C} /{ }^{12} \mathrm{C}$ and nitrogen ${ }^{15} \mathrm{~N} /{ }^{14} \mathrm{~N}$ ) analyses in order to compare isotopic niches between fish species and reveal with which resident fish species the exploitative competition of round goby can be expected; and

- To evaluate the contribution of round goby to the nutrition of top predators of the Curonian Lagoon, European perch, Perca fluviatilis Linnaeus, 1758; pike-perch, Sander lucioperca (Linnaeus, 1758); great cormorant, Phalacrocorax carbo; and grey heron, Ardea cinerea, in particular, and consequently, to assess the role of the invader in the lagoon food web.

\section{MATERIALS AND METHODS}

Study site. The Curonian Lagoon is a large $\left(1584 \mathrm{~km}^{2}\right)$, shallow (average depth $3.8 \mathrm{~m}$ ) freshwater basin connected to the South-Eastern Baltic Sea by a narrow $(0.4-1.1 \mathrm{~km})$ strait of Klaipeda port (Žaromskis 1996). The strait is an 11-km-long channel, with artificially deepened waterways down to $14 \mathrm{~m}$ depth (Gasiūnaite et al. 2008). The lagoon is classified as an eutrophic- to hypertrophic water body, with fresh-brackish water gradient in the northern part. Its typical limnological features are described in detail by Gasiūnaitè et al. (2008).

Fish community of the Curonian Lagoon is dominated by roach, perch, ruffe, white bream, Blicca bjoerkna (Linnaeus, 1758), and freshwater bream (Repečka 2003). The same species composition is found in juvenile fish assemblage of littoral habitats (Žiliukienė 1998, Repečka 2003, Žiliukas 2003). The main top predators in the ecosystem are represented by large-sized predatory fish species, perch and pike-perch, and piscivorous birds, such as great cormorant and grey heron (Repečka 2003, Žydelis and Kontautas 2008, Pūtys and Zarankaitė 2010).

Fish community analysis. Fish samples for estimation of occurrence and abundance of round goby in the Curonian Lagoon were collected during a six-year period, from 2007 to 2012. The presence of round goby in the shallow littoral zone (down to $1 \mathrm{~m}$ depth) was investigated with a beach seine at 17 study sites (bottom: sand cover $>60 \%$, macrophyte cover $<15 \%$, on a few occasions silt cover around $50 \%$ and the presence of stone belts) located in the northern and central parts of the Curonian Lagoon (Fig. 1). Each year, 10 to 14 study sites were surveyed once per year during August or September. A beach seine with wings 8- or 7-m long (mesh size 10 and $5 \mathrm{~mm}$, respectively) was used; the opening of the seine bag was $1.2 \times 1.3 \mathrm{~m}$ (width $\times$ height), and the length of $3 \mathrm{~mm}$ mesh-sized codend was $3 \mathrm{~m}$. Beach seining hauls were $50 \mathrm{~m}$ long and 20 $\mathrm{m}$ width. The distance was assessed in accordance to beach seine length $(30 \mathrm{~m})$. The area sampled with the beach seine was approximately $1000 \mathrm{~m}^{2}$ on each sampling. To supplement the beach seine catches during 2009-2010, the presence of round goby at study sites in $2.0-3.5 \mathrm{~m}$ depths was investigated using gill nets. On each sampling occasion, from one to six standard multipanel gill nets (40 m length, mesh sizes 14, 17, 21.5, 25, $30 \mathrm{~mm}$ ) were used.

\footnotetext{
${ }^{*}$ Bur M.T., Edwards W.H., Kocovsky P.M., Porta M.J. Stapanian M.A. 2007. Prey fish consumption by double-crested cormorants in western Lake Erie near West Sister Island, Ohio. Report to Great Lakes Fishery Commission, Lake Erie Committee Meeting. Ypsilanti, MI, USA.
} 


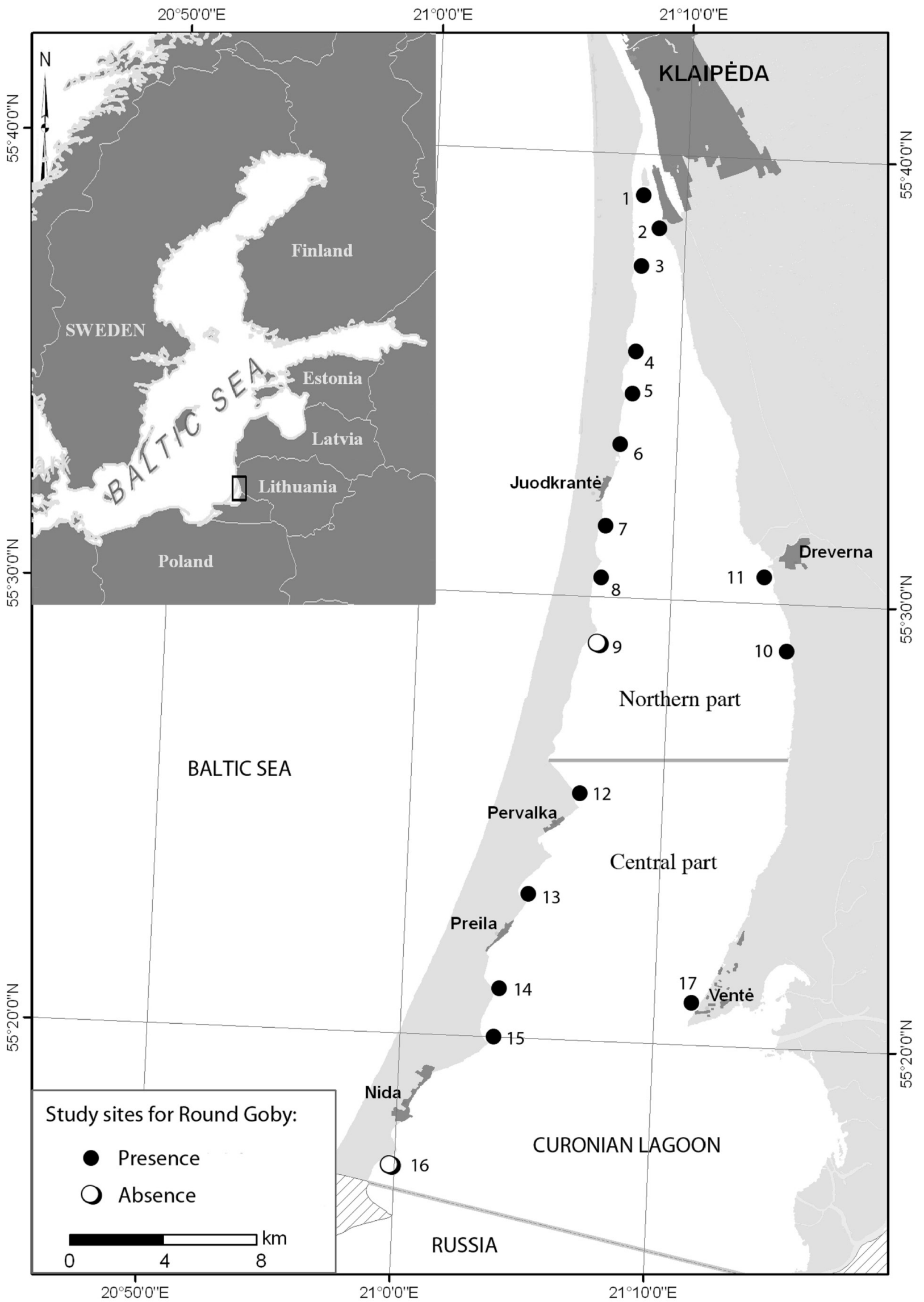

Fig. 1. Location of study sites in the northern and central parts of the Curonian Lagoon; Black- and white dots indicate presence and absence of Neogobius melanostomus within the study period (2007-2012) 
Collected fish were identified to species, measured to the nearest $1 \mathrm{~mm}$ (TL) and weighed to the nearest $0.1 \mathrm{~g}$. Obtained results allowed assessing round goby abundance (ind. per $1000 \mathrm{~m}^{2}$ ) and its proportion in the fish community (for gill net catches only round goby proportion was assessed). The study duration was divided into three biannual periods (2007-2008, 2009-2010, and 2011-2012), and mean abundances per study site for these periods were utilised for statistical comparisons (Table 1). In particular, abundances of the invader in mouth of the lagoon, which was invaded first (1-3 study sites, Fig. 1), and in the northern part of the lagoon (5-8 study sites, Fig. 1) for which estimates for all biannual periods were available were compared between periods, applying the Kruskal-Wallis test and the Student's $t$-tests on square root transformed abundances.

Gut content analysis. Gut contents of 24 specimens collected in the northern part of the lagoon (site 8, Fig. 1) in 2009 were analysed for the diet composition of round gobies. Gobies were euthanized and preserved in 4\% formaldehyde solution. Each individual was measured and weighed as described above. Food items were identified to the lowest possible taxa, counted and weighed, and their proportions in the total gut content biomass were assessed. The volume (biomass) of unidentifiable particles was proportionally divided among identified food items.

Stable isotope analysis. Round gobies for stable isotope analysis (SIA) were taken from the northern part of the Curonian Lagoon (site 4, Fig. 1) in August of 2009 and 2010. Other fish samples were collected from all Lithuanian part of the Curonian Lagoon from August till September in 2010 (Table 2). The white muscles of fish were dissected from the dorsal part and placed into foil cups (2-4 individuals of the same size per replicate), and stored frozen at $-20^{\circ} \mathrm{C}$. Perch and roach were divided into three length groups (see Table 2) as it is known that these fish undergo ontogenetic niche shifts (Hjelm et al. 2000, Horppila et al. 2000, Svanbäck end Eklöv 2002, Hjelm et al. 2003). Feathers of great cormorant (23 samples in total) and grey heron (6 samples in total) were collected at the colony of great cormorants, near town Juodkrante in July 2010 (Fig. 1). The middle parts of feathers were cut and placed individually into foil cups for the SIA.

All samples were oven dried at $60^{\circ} \mathrm{C}$ for $48 \mathrm{~h}$ and ground to fine powder in an agate mortar. Samples were analysed at the Stable Isotope Facility, UC Davis, USA. Carbon and nitrogen stable isotope ratios were determined by continuous flow isotope ratio mass spectrometry. Stable isotope ratios $(\%)$ are given using the $\delta$ notation expressed in units per mil as follows:

$$
\delta=[R-1] \times 1000
$$

where: $R={ }^{13} \mathrm{C} /{ }^{12} \mathrm{C}$ or ${ }^{15} \mathrm{~N} /{ }^{14} \mathrm{~N}$.

The global references were atmospheric $\mathrm{N}_{2}$ for the ${ }^{15} \mathrm{~N} /{ }^{14} \mathrm{~N}$ ratio, and Vienna Pee Dee belemnite for the

Table 1

Abundance and proportions of round goby, Neogobius melanostomus, in the total fish number and the total catch weight at study sites in the northern- and central parts of the Curonian Lagoon within 2007-2012

\begin{tabular}{|c|c|c|c|c|c|c|c|c|c|}
\hline \multirow{2}{*}{ Site No. } & \multicolumn{3}{|c|}{$2007-2008$} & \multicolumn{3}{|c|}{ 2009-2010 } & \multicolumn{3}{|c|}{ 2011-2012 } \\
\hline & $N$ & $P_{N}$ & $\mathrm{P}_{\mathrm{Q}}$ & $N$ & $P_{N}$ & $\mathrm{P}_{\mathrm{Q}}$ & $N$ & $P_{N}$ & $P_{Q}$ \\
\hline 1 & 3.0 & 0.4 & 0.3 & 0 & 0 & 0 & 0 & 0 & 0 \\
\hline 2 & 9.5 & 0.9 & 2.6 & 4.5 & 1.3 & 1.7 & 0 & 0 & 0 \\
\hline 3 & 39.5 & 11.5 & 3.8 & 0 & $0(0.3)$ & 0 & 2 & 0.02 & 0.1 \\
\hline 4 & - & - & - & 20.0 & $0.4(0.4)$ & 0.6 & 0 & 0 & 0 \\
\hline 5 & 0 & 0 & 0 & 48.5 & $36.0(0)$ & 39.7 & 4 & 0.02 & 0.1 \\
\hline 6 & 12.0 & 7.9 & 3.9 & 1.0 & $0.1(0)$ & 0.1 & 0 & 0 & 0 \\
\hline 7 & 3.0 & 0.7 & 0.2 & 125.5 & $8.7(0.2)$ & 23.4 & 9.5 & 0.2 & 1.1 \\
\hline 8 & 0 & 0 & 0 & 10.0 & $1.9(0)$ & 5.2 & 0 & 0 & 0 \\
\hline 9 & - & - & - & 0 & $0(0)$ & 0 & 0 & 0 & 0 \\
\hline 10 & 0.5 & 0.1 & 0.01 & - & - & - & - & - & - \\
\hline 11 & 0 & 0 & 0 & - & - & - & - & $\left(0.1^{\mathrm{S}}\right)$ & - \\
\hline 12 & 0 & 0 & 0 & 2.0 & $1.5(1.1)$ & 3.2 & 11.0 & 0.1 & 0.5 \\
\hline 13 & 0 & 0 & 0 & 4.0 & 0.2 & 1.0 & 0 & 0 & 0 \\
\hline 14 & - & - & - & 1.0 & $0.4(0.6)$ & 0.04 & 0 & 0 & 0 \\
\hline 15 & 0 & 0 & 0 & 0 & $0(0.1)$ & 0 & 0 & 0 & 0 \\
\hline 16 & 0 & 0 & 0 & 0 & 0 & 0 & 0 & 0 & 0 \\
\hline 17 & 0 & 0 & 0 & 0.5 & $0.1(0)$ & 0.1 & - & - & - \\
\hline
\end{tabular}

$N=$ Abundance [ind. per $1000 \mathrm{~m}^{2}$ ]; $P_{N}=$ total fish number [proportions of Neogobius melanostomus in the total fish number] (in brackets estimates from gill netting); $P_{Q}=$ total catch weight [proportions of Neogobius melanostomus in the total catch weight] ; ${ }^{S}$ Data obtained from a single gill net fishing performed in 2011; Study site numbers are the same as in Fig. 1 (1-11 are sites in northern part of the lagoon, while 12-17 are sites in central part). 
${ }^{13} \mathrm{C} /{ }^{12} \mathrm{C}$ ratio (Fry 2006). Typical precision for a single analysis was $\pm 0.1 \%$ for $\delta^{13} \mathrm{C}$ and $\pm 0.3 \%$ for $\delta^{15} \mathrm{~N}$. The mean $\mathrm{C}: \mathrm{N}$ ratio in fish tissues (a correlate of lipid concentration; DeNiro and Epstein 1977) was very low in this study $(3.2 \pm 0.4)$ and did not affect $\delta^{13} \mathrm{C}$ values significantly (Spearman rank order correlation: $\rho=-0.23, P>0.05$ ). Trophic position calculations. Due to great temporal and spatial variability of stable isotope (SI) composition in primary producers of the lagoon the trophic chain could be reconstructed using SI signatures of several primary consumers (Lesutienė unpublished*). Usually, filter-feeding bivalves, such as zebra mussel, Dreissena polymorpha (Pallas, 1771), are considered as integrators of the pelagic phytoplankton signature and gastropods, such as Lymnaea sp., of benthic or littoral algal sources (Post 2002). We used two isotopically distinct primary consumer groups: base 1 -mussels: D. polymorpha and Unio sp. $\left(\delta^{15} \mathrm{~N}=\right.$ $10.4 \%$, $\delta^{13} \mathrm{C}=-30.3 \%$ ) and base 2 -gastropods: littoral Lymnaea sp. and offshore Valvata sp. $\left(\delta^{15} \mathrm{~N}=9.3 \%\right.$, $\delta^{13} \mathrm{C}$ $=-25.6 \%$ ) to calculate the trophic position (TP) by equation (Post 2002):

$\mathrm{TP}=2+\left(\delta^{15} \mathrm{~N}_{\text {consumer }}-\left[\delta^{15} \mathrm{~N}_{\text {basel }} \times \alpha+\delta^{15} \mathrm{~N}_{\text {base } 2} \times(1-\alpha)\right]\right) \cdot 2.9^{-1}$ where: $\delta^{15} \mathrm{~N}_{\text {consumer }}$ is nitrogen isotope ratio in a consumer of interest; $\delta^{15} \mathrm{~N}_{\text {baseline }}$ is nitrogen isotopic baseline of a primary consumer, corresponding to TP $=2 ; \alpha$ is the proportion of nitrogen isotopes in a consumer, ultimately derived from sources similar to gastropods (base 1). Assuming the same flow rate of nitrogen and carbon from diet to a predator, $\alpha$ was estimated using $\delta^{13} \mathrm{C}$ by equation (Post 2002): $\alpha=\left(\delta^{13} \mathrm{C}_{\text {consumer }}-\delta^{13} \mathrm{C}_{\text {base } 2}\right) \cdot\left(\delta^{13} \mathrm{C}_{\text {base } 1}-\delta^{13} \mathrm{C}_{\text {base } 2}\right)^{-1} \cdot$

This two-end-member-mixing model allows for the differentiation between two sources, such as the littoral and pelagic food webs, and assumes that there is little trophic fractionation of carbon, and the mixing is linear (Post 2002). It also assumes that fractionation factors between resources and consumers incorporated into the model were $1.3 \%$ for $\delta^{13} \mathrm{C}$ and $2.9 \%$ o for $\delta^{15} \mathrm{~N}$ for fish (muscle tissue) (McCutchan et al. 2003), while 2.16\% for $\delta^{13} \mathrm{C}$ and $3.84 \%$ or for $\delta^{15} \mathrm{~N}$ were used for birds (feather tissue) (Caut et al. 2009).

Isotopic source proportions. Isotopic signatures of food source can be used to estimate proportional contribution of each source to the assimilated diet of consumers (Quevedo et al. 2009, Jaschinski et al. 2011). In general, signatures of $n$ isotopes are required to obtain a unique solution for proportional contributions of $n+1$ source. In the case of a system exceeding $n+1$ sources, the software IsoSource v. 1.3 (Phillips and Gregg 2003) generates a distribution of all the feasible solutions for a given isotopic mixture. We used IsoSource and the mean values of $\delta^{13} \mathrm{C}$ and $\delta^{15} \mathrm{~N}$ from putative prey to estimate the most likely proportional contributions of round goby to the average isotopic signatures of piscivorous fish and birds. All species contributing $>5 \%$ by number or biomass in fish catches, excluding large, $>20 \mathrm{~cm}$, species/size groups avoided by predators, were used as potential prays in the mixing models. Round goby and other dominant fish species - perch, roach, ruffe, and bleak, Alburnus alburnus (Linnaeus, 1758)—were incorporated into the mixing

Table 2

Summary of stable isotope analysis of benthivorous fish and top predators from the Curonian Lagoon in 2010

\begin{tabular}{|c|c|c|c|c|c|c|}
\hline TG & Species & $\mathrm{TL}[\mathrm{cm}]$ & $N$ & $\delta^{13} \mathrm{C}[\% 0]$ & $\delta^{15} \mathrm{~N}[\% 0]$ & TP \\
\hline \multirow{13}{*}{ 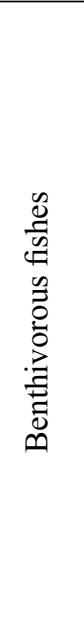 } & Abramis brama & $23.1 \pm 5.3$ & 6 & $-28.1 \pm 0.5$ & $14.1 \pm 0.5$ & $3.3 \pm 0.2$ \\
\hline & Alburnus alburnus & $12.5 \pm 1.8$ & 6 & $-28.9 \pm 0.4$ & $12.9 \pm 0.4$ & $2.9 \pm 0.1$ \\
\hline & Blicca bjoerkna & $18.1 \pm 4.3$ & 9 & $-29.3 \pm 0.6$ & $15.6 \pm 0.4$ & $3.8 \pm 0.2$ \\
\hline & Gobio gobio & $10.3 \pm 3.0$ & 6 & $-29.0 \pm 0.1$ & $14.4 \pm 0.4$ & $3.4 \pm 0.2$ \\
\hline & Gymnocephalus cernua & $10.7 \pm 3.5$ & 6 & $-27.6 \pm 0.1$ & $13.0 \pm 0.2$ & $3.0 \pm 0.1$ \\
\hline & Leuciscus leuciscus & $8.9 \pm 0.6$ & 3 & $-28.8 \pm 0.2$ & $14.4 \pm 0.2$ & $3.4 \pm 0.04$ \\
\hline & Neogobius melanostomus & $10.4 \pm 1.7$ & 7 & $-27.1 \pm 0.6$ & $13.0 \pm 0.3$ & $3.0 \pm 0.1$ \\
\hline & Perca fluviatilis $\mathrm{S}$ & $8.9 \pm 0.3$ & 3 & $-29.1 \pm 0.1$ & $14.5 \pm 0.1$ & $3.4 \pm 0.03$ \\
\hline & Perca fluviatilis $\mathrm{M}$ & $13.1 \pm 1.0$ & 3 & $-27.4 \pm 0.3$ & $14.4 \pm 0.3$ & $3.5 \pm 0.1$ \\
\hline & Rutilus rutilus $\mathrm{S}$ & $11.2 \pm 0.6$ & 3 & $-29.9 \pm 0.3$ & $14.1 \pm 0.5$ & $3.2 \pm 0.1$ \\
\hline & Rutilus rutilus $\mathrm{M}$ & $14.3 \pm 0.9$ & 3 & $-28.1 \pm 0.1$ & $12.6 \pm 0.3$ & $2.9 \pm 0.1$ \\
\hline & Rutilus rutilus $\mathrm{L}$ & $23.1 \pm 1.0$ & 3 & $-29.0 \pm 0.2$ & $14.8 \pm 0.2$ & $3.5 \pm 0.1$ \\
\hline & Vimba vimba & $26.7 \pm 1.6$ & 3 & $-26.8 \pm 0.5$ & $14.2 \pm 0.4$ & $3.6 \pm 0.1$ \\
\hline \multirow{4}{*}{ 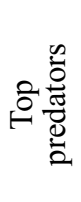 } & Perca fluviatilis L & $27.2 \pm 1.4$ & 3 & $-26.6 \pm 0.3$ & $15.5 \pm 0.2$ & $3.9 \pm 0.1$ \\
\hline & Sander lucioperca $\mathrm{L}$ & $28.3 \pm 5.4$ & 6 & $-26.2 \pm 0.7$ & $16.1 \pm 0.6$ & $4.1 \pm 0.2$ \\
\hline & Ardea cinerea & - & 6 & $-27.3 \pm 0.9$ & $16.4 \pm 0.4$ & $3.8 \pm 0.1$ \\
\hline & Phalacrocorax carbo & - & 23 & $-25.7 \pm 0.8$ & $15.9 \pm 0.3$ & $3.7 \pm 0.1$ \\
\hline
\end{tabular}

Values are mean \pm standard deviation; $\mathrm{TG}=$ trophic group; $\mathrm{TL}=$ total length of fish; $N=$ number of replicates; $\delta^{13} \mathrm{C}$ and $\delta^{15} \mathrm{~N}$ are stable isotope values; TP = trophic position; fish size categories: $\mathrm{S}=$ small, $\mathrm{M}=$ medium, $\mathrm{L}=$ large.

\footnotetext{
${ }^{*}$ Lesutiené J. 2009. Food web of the Curonian Lagoon: Organic matter sources and feeding of mysids. Doctoral thesis. Klaipeda University, Klaipeda, Lithuania.
} 
model as end-members. All possible combinations of prey contributions with an increment of $1 \%$ were analysed. These predicted mixture signatures were compared with the measured values in the top predators. If they were within a tolerance of $0.1 \%$, they were considered feasible solutions. Prior to the analyses, predator stable isotopes values were corrected for trophic changes of $\delta^{13} \mathrm{C}$ and $\delta^{15} \mathrm{~N}$ by applying diet-tissue fractionation factors described above.

This study has been carried out in accordance with the regulations of the Ministry of Environment of the Republic of Lithuania, all permits for relevant fish collection were obtained during the investigation.

\section{RESULTS}

Fish community composition. Beach seine catches in the littoral zone showed the perch, the roach, and the ruffe to be the dominant fish species by the proportion of number and biomass (Fig. 2). Bleak was also a common fish in the catches at some study sites, although its mean proportion never exceeded 10\%. Gudgeon, Gobio gobio (Linnaeus, 1758), was abundant in the central part of the lagoon; its share in the littoral catches was $16 \%$ by number and $17 \%$ by biomass, while in the northern part its proportion did not exceed 3\% (Fig. 2). The mean propor- tion of round goby in the northern part of the lagoon was $3.1 \%$ by number and $4.3 \%$ by biomass. While that in the central part of the lagoon was estimated at $0.1 \%$ and $0.5 \%$, respectively.

The dominant fish in gill net catches from the deeper parts of the lagoon also were perch, roach, and ruffe. Together their proportion by number and biomass was more than $70 \%$ (Fig. 2). White bream was common in the gill net catches from the central part of the lagoon. In gill net catches, the mean proportion of round goby by number was generally lower than that recorded by the seine, and was estimated at $0.2 \%$ in the lagoon.

Round goby expansion and abundance. Round goby was recorded at 6 of 9 surveyed littoral sites located in the northern part of the Curonian Lagoon during 2007-2008. The fish occurred at three new sites during 2009-2012. Additionally, the newcomer was observed in the gill nets catch at a new study site (site 11, Table 1) in 2011. In total, round goby was recorded at 10 of 11 study sites from the northern part of the lagoon (Table 1, Fig. 1). In the central part of the Curonian Lagoon round goby was absent from the littoral fish catches during 2007-2008. It was only discovered in 2009 and since then it was recorded at 5 of 6 study sites by the seine or gill nets

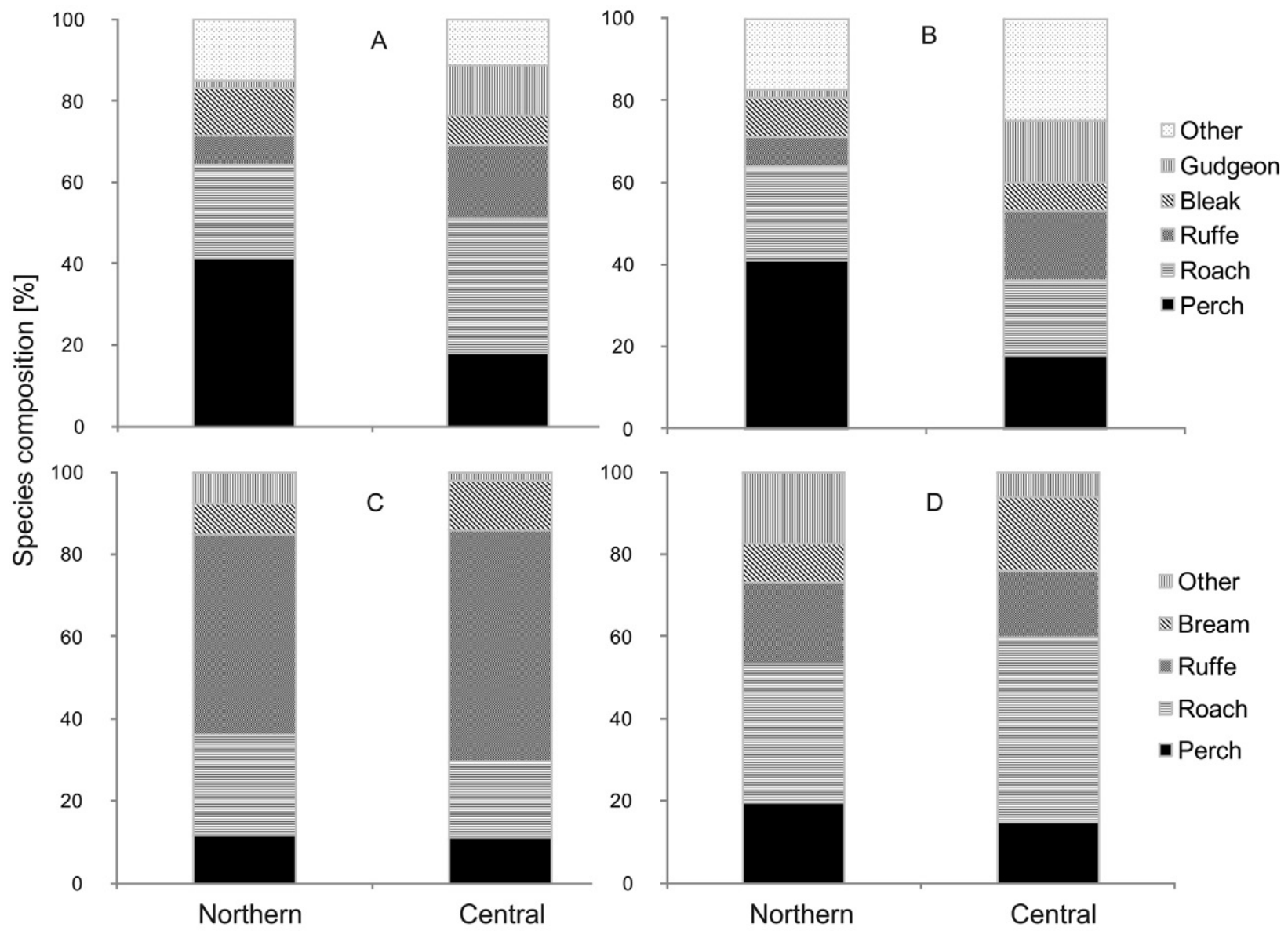

Fig. 2. Proportion by numbers and biomass of fish species in seine catches within 2007-2012 (A and B, respectively) and in gill nets catches within 2009-2010 (C and D, respectively) from the northern and central parts of the Curonian Lagoon; Fish species: Perca fluviatilis (perch), Rutilus rutilus (roach), Gymnocephalus cernua (ruffe), Gobio gobio (gudgeon), Alburnus alburnus (bleak), Blicca bjoerkna (bream) 
(Table 1, Fig. 1). Round goby was not observed in the southernmost study site (site 16, Fig 1) during the entire period. When comparing records obtained by the beach seine and gill nets in 2009-2010, the newcomer was usually present in the gill net catches at sites where it was also sampled by the seine, and in total it was recorded at 6 of 11 study sites located in both parts of the lagoon (Table 1). On 10 occasions of 17 when both methods at a site were applied, round goby was recorded. Among these catches, round goby proportion by number on the mean ( \pm standard error) was substantially larger from the beach seine than gill nets $(9.59 \% \pm 4.9 \%$ vs. $0.38 \% \pm 0.19 \%)$, however, this difference only can be interpreted as a tendency (Wilcoxon matched pairs test: $Z=1.4$, $P=0.18$; and dependent samples $t$-test on arcsin-transformed proportions, $d f=9, t=2.04, P=0.072$ ).

In general, estimated abundances of round goby at study sites varied a lot (Table 1), and the highest recorded abundance was 251 ind. per $1000 \mathrm{~m}^{2}$ at Juodkrante settlement in 2009. When present, the species proportion in total catches with respect to numbers and biomass varied from $0.1 \%$ to $45.8 \%$ and from $0.03 \%$ to $51.4 \%$, correspondingly. For trends in abundance, the mouth and the northern part of the lagoon (sites 1-3 and sites 5-8, respectively; Table 1, Fig. 1) were analysed. In the mouth, where the early occurrence of round goby was observed, the abundance during 2007-2008 was substantially larger than that estimated later on (mean \pm SE: $17.3 \pm 11.2$ vs. $1.1 \pm 0.8$ ind. per $1000 \mathrm{~m}^{2}$ ), and this pattern was significant (Kruskal-Wallis test: $H(1, N=9)=4.65, P=0.031$; $t$-test: $d f=7, t=2.97, P=0.021)$. In contrast to that, at the study sites $5-8$ in the northern part of the lagoon, i.e., the area which presumably was colonised later than the mouth (see Fig. 1), recorded abundances were higher during 2009-2010 than those observed before and later (46.2 \pm 28.4 vs. $3.6 \pm 1.78$ ind. per $\left.1000 \mathrm{~m}^{2}\right)$, and this pattern tended to be significant (Kruskal-Wallis test: $H(1, N=12)=3.62, P=0.057$; $t$-test: $\mathrm{df}=10, t=2.55$, $P=0.029)$.

The colonisation of the central part of the Curonian Lagoon, as described above, started in 2009 (Table 1, Fig. 1), while estimated abundances in individual catches (on the cases of species presence) varied between 1 and 22 ind. $1000 \mathrm{~m}^{-2}$.

Stable isotopes. The $\delta^{13} \mathrm{C}$ and $\delta^{15} \mathrm{~N}$ isotopic composition differed significantly between benthivorous fish species in the Curonian Lagoon (one-way ANOVA's: $\delta^{13} \mathrm{C}, F_{13,50}=33.2, P<0.0001 ; \delta^{15} \mathrm{~N}, F_{13,50}=41.5$, $P<0.0001) . \delta^{13} \mathrm{C}$ values of benthivorous fish were most depleted in small roach $-29.9 \%$ and most enriched in the vimba bream, Vimba vimba (Linnaeus, 1758), (-26.8\%o). $\delta^{15} \mathrm{~N}$ values of benthivorous fish ranged from $12.6 \%$ (medium roach) to $15.6 \%$ (white bream). The piscivorous pike-perch, large perch, great cormorants and grey herons were more enriched in ${ }^{15} \mathrm{~N}$, relatively to benthivorous fish species (Table 2). The majority of non-piscivorous fish relied on ${ }^{13} \mathrm{C}$-depleted sources, while round goby, ruffe, vimba bream, and medium perch had ${ }^{13} \mathrm{C}$-enriched values
(Fig. 3). The mean trophic position (TP) of non-piscivorous fish ranged from 2.85 (medium roach) to 3.78 (white bream). Predatory fish (large perch and pike-perch) occupied the fourth trophic level and proved to be the top predators in the lagoon.

The mean $\delta^{13} \mathrm{C}$ value of round goby overlapped with vimba bream and medium perch (Fisher LSD post-hoc test, $p>0.06)$. Although round goby and ruffe were plotted close to each other in the isotopic bi-plot (Fig. 3), the difference between mean $\delta^{13} \mathrm{C}$ values of these two benthivorous fish species was statistically reliable (Fisher LSD post-hoc test, $P=0.01$; and Mann-Whitney U test: $Z=-1.9, P=0.06)$. Mean $\delta^{15} \mathrm{~N}$ values of round goby overlapped with ruffe, bleak, and medium roach (Fisher LSD post hoc, test, $P>0.22$ ) (Fig. 3).

When considering the ontogenetic pattern, $\delta^{13} \mathrm{C}$ values of round goby became increasingly depleted with increasing body size (linear regression: $r^{2}=0.42, F_{(1,11)}=9.63$, $P=0.02)$. However, $\delta^{15} \mathrm{~N}$ values of gobies did not change with fish size (linear regression: $r^{2}=0.28, F_{(1,11)}=0.93$, $P=0.35)$ (Fig. 4).

Diet of round goby and top predators. The gut content analysis revealed significant variation of diet composition over the study years. Dreissena polymorpha dominated $(72 \%)$ in the diet of 2007 whereas chironomids (larvae and pupae) dominated (79\%) in 2009 (Fig. 5). Amphipods constituted $20 \%$ and $12 \%$ in 2007 and 2009, respectively. Prey items which contribution did not exceed $2 \%$ included ostracods, mysids, and the New Zealand mud snails, Potamopyrgus antipodarum.

According to the stable isotope mixing model perch and roach were the dominant fish species in the diet of large-sized perch and pike-perch, and together comprised more than $50 \%$ of their diet (Table 3). It was estimated that round goby constituted $\sim 17 \%$ of large-sized perch and pike-perch diet in the Curonian Lagoon. According to the mixing model, piscivorous birds showed preferences to roach and bleak. Proportion of these two fish species in the birds' diet constituted more than 63\%. Round goby contribution to the diet of great cormorant and grey heron was estimated at $11.9 \%$ and $6.9 \%$, respectively.

\section{DISCUSSION}

This study clearly demonstrated the ongoing expansion of round goby in the Curonian Lagoon. The newcomer was recorded in almost all study sites during a six-year period, suggesting its successful establishment in the entire Lithuanian part of the lagoon. Over a seven-year period, the invader spread along the $\sim 42 \mathrm{~km}$ shore line inside the lagoon, suggesting dispersal rate at about $6 \mathrm{~km}$ per year. Information from anglers, however, indicated even faster dispersal rate of this alien fish. First cases of solitary individuals of round goby from the southernmost sites (Nida town) were reported by anglers in 2007 (Rakauskas et al. 2008). If to consider this information, the dispersal rate can be evaluated at about $10 \mathrm{~km}$ per year. Although round gobies are typically sedentary fish with limited home ranges (Björklund and Almqvist 2010), 
some individuals occasionally can move long distances. Wolfe and Marsden (1998) reported a maximum migration of $2 \mathrm{~km}$ in 218 days for this species. Long (up to 10 $\mathrm{km})$ migrations in late autumn or early spring when gobies migrate to- or from deeper waters also were reported by Berg (1949). There is no shipping carrying ballast waters within the Curonian Lagoon, therefore the transfer of round goby larvae by this vector is not likely. Round goby is not used as a favourite bait for piscivorous fish by anglers. Thus, we suggest that the gradual expansion of round goby from the north to south within the Curonian Lagoon was proceeding naturally with the dispersal rate of 6-10 km per year. Consequently, the further southward expansion of round goby into the lagoon waters of the Kaliningrad region (Russia) seems unavoidable. The first specimens of the invader were already recorded in the Kaliningrad part of the Curonian Lagoon in 2010 (T. Golubkova personal communication). Assuming the same as observed rate of colonisation, it could be predicted that the entire lagoon will be colonised before 2015 .

A decrease of round goby numbers in catches from the mouth of the lagoon which was colonised first since 2008, an increase of abundance in 2009-2010 and a subsequent decrease of that during 2011-2012 in the northern part of the lagoon (presumably colonised later than the mouth) were observed. Such a pattern of abundance change dur- ing the study period suggests that the abundance of round goby in the northern part of the Curonian Lagoon may be already stabilised. A decrease of abundance of a species after colonisation of a new area, i.e., a phase of population increase, is a well-known phenomenon in invasion dynamics (Reise et al. 2006). Meanwhile, the colonisation of the central part of the lagoon began only in 2009 , thus the abundance increase of the newcomer may be expected there in future. It should be noted, that the round goby densities estimated in the Curonian Lagoon (0.001-0.251 ind. per $\mathrm{m}^{2}$ ) were substantially lower in comparison to those reported for other invaded water bodies. Very high densities of this species (5-133 ind. per $\mathrm{m}^{2}$ ) have been estimated in Lake Erie (Weimer and Keppner 2000, Vanderploeg et al. 2002, Steinhart et al. 2004) and southern Lake Michigan (Charlebois et al. 1997, Chotkowski and Marsden 1999), while the largest densities in the shallow waters of Puck Bay (Gulf of Gdansk) were up to 3.5 ind. per $\mathrm{m}^{2}$ (Sapota and Skóra 2005).

It is possible that quantitative sampling (trawling a beach seine in the shallow littoral during the daytime), employed in this study, may not be sufficient for a gross estimation of the density of this bottom-dwelling fish species. The majority of individuals may reside in deeper waters (over $1 \mathrm{~m}$ depth) during the daytime. Consequently, the true density of round goby in the lit-

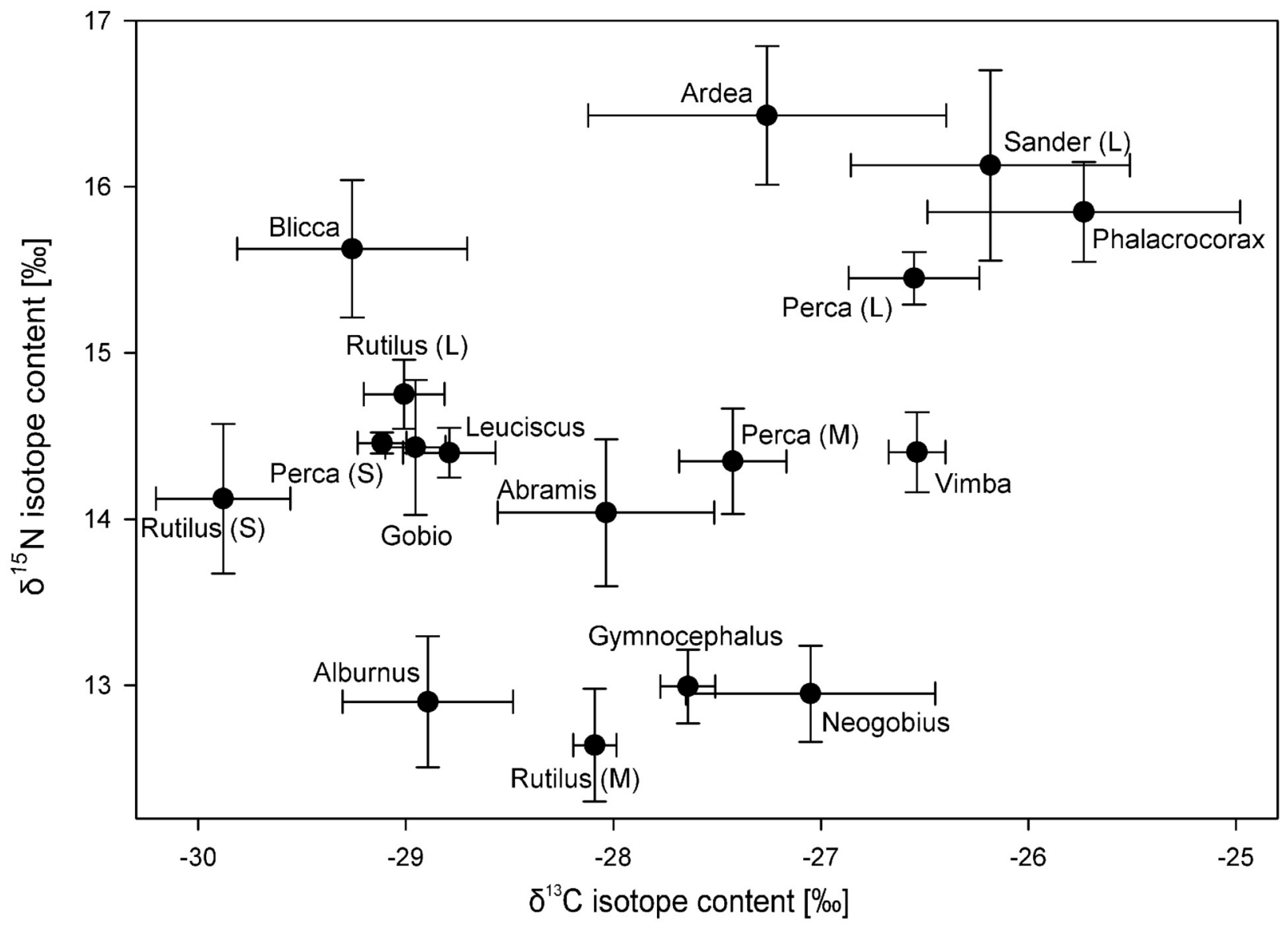

Fig. 3. Isotopic bi-plot showing $\delta^{13} \mathrm{C}$ and $\delta^{15} \mathrm{~N}$ values (mean \pm standard deviation) for different fish and bird species of the Curonian lagoon in 2010 
toral zone may be higher than our data suggest. However, the comparison of round goby proportions in catches from the littoral and offshore zones (beach seine vs. gill nets) of the lagoon did not suggest a preference of the species for deep lagoon waters, which round goby presumably avoids, escaping fish predation. Thus, round goby may prefer the intermediate depths in the lagoon avoiding avian predation in the shallow waters and fish predation in the offshore zone, and this question warrants special investigation.

On the other hand, predation of piscivorous fish and birds may be contributing to relatively low densities of round gobies in the Curonian Lagoon as stable isotope mixing models showed round goby to be a very likely food source in the diet of these predators. The predators, such as perch and pike-perch, which have been reported for their marked reliance on round goby in another study (Almqvist et al. 2010), are common and abundant fish species in the Curonian Lagoon. Moreover, numerous colonies of grey herons and great cormorants, which are also known as important predators of round goby (Jakubas 2004, Bzoma 1998), are located next to the lagoon. Finally, the burbot, Lota lota (Linnaeus, 1758), and the northern pike, Esox lucius Linnaeus, 1758, also consume round goby in significant amounts as it has been documented by their stomach content analysis (Johnson et al. 2005, Hensler et al. 2008, Jacobs et al. 2010, Reyjol et al. 2010, Madenjian et al. 2011, Płąchocki et al. 2012).

In respect to estimated contribution of round goby to the diet of top predators in the lagoon based on mixing modelling, the share of this newcomer may be slightly overestimated. That may result from consumption by the top predators of fish from the coastal waters of the Baltic Sea. Such food items may seasonally constitute a considerable part in the diet content of piscivorous fish and birds exploiting the Curonian Lagoon. Recent analysis of pellets of great cormorant showed that sea fish comprised more than $13 \%$ (by biomass) of the diet of this bird in 2010 (Pūtys unpublished*). Predatory large-sized perch and pike-perch are also known of seasonal feeding migrations to the coastal waters of the Baltic Sea (Ložys 2004).
Thus, measured mean isotopic values of cormorant and predatory fish species might be slightly enriched in $\delta^{13} \mathrm{C}$ values due to feeding in the sea, which usually has a more enriched in ${ }^{13} \mathrm{C}\left(\delta^{13} \mathrm{C} \sim 21 \%\right.$ ) primary and secondary production than surrounding freshwater bodies (Rolff and Elmgren 2000). Consequently, the share of round goby, which has the most enriched $\delta^{13} \mathrm{C}$ signal among nonpredatory fish in the lagoon, might be slightly over-valued in predator's diet.
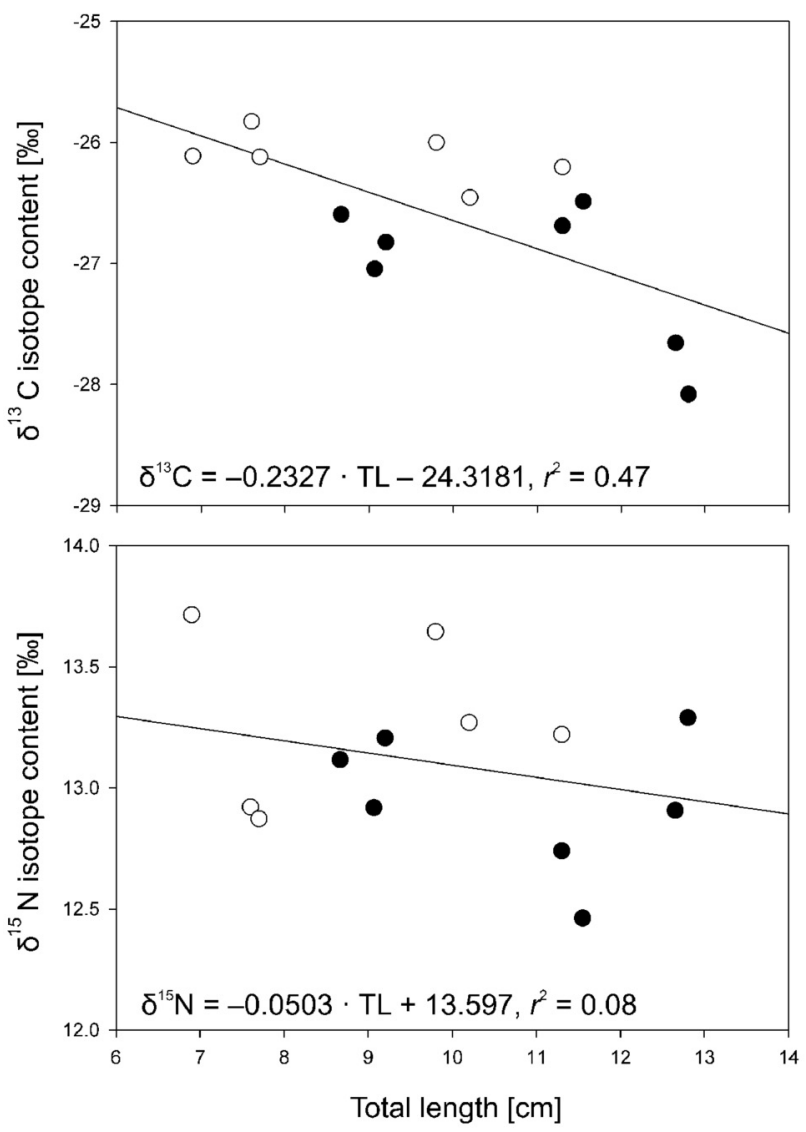

Fig. 4. Relation between total body length and $\delta^{13} \mathrm{C}$ (top) or $\delta^{15} \mathrm{~N}$ (bottom) values for round gobies, Neogobius melanostomus, from the Curonian Lagoon collected in 2009 (white dots) and 2010 (black dots)

Table 3

Diet composition of top predators from the Curonian Lagoon in 2010; percent contributions of fish prey species to predator's nutrition

\begin{tabular}{lcccc}
\hline \multirow{2}{*}{ Prey species } & \multicolumn{4}{c}{ Top predators } \\
\cline { 2 - 5 } & Sander lucioperca & Perca fluviatilis & $\begin{array}{c}\text { Phalacrocorax } \\
\text { carbo }\end{array}$ & Ardea cinerea \\
\hline Perca fluviatilis S & $12.1 \pm 10.6$ & $9.3 \pm 7.9$ & $2.8 \pm 2.8$ & $11.0 \pm 8.9$ \\
Perca fluviatilis M & $16.5 \pm 13.6$ & $9.8 \pm 8.3$ & $3.0 \pm 3.0$ & $6.2 \pm 5.5$ \\
Gymnocephalus cernua & $15.6 \pm 13.6$ & $15.7 \pm 13.8$ & $7.3 \pm 6.7$ & $12.4 \pm 11.0$ \\
Rutilus rutilus S & $9.8 \pm 8.3$ & $10.8 \pm 9.3$ & $3.7 \pm 3.6$ & $18.3 \pm 11.4$ \\
Rutilus rutilus M & $15.4 \pm 13.5$ & $19.2 \pm 14.3$ & $51.5 \pm 15.8$ & $18.1 \pm 13.0$ \\
Neogobius melanostomus & $17.5 \pm 13.4$ & $17.4 \pm 14.3$ & $11.9 \pm 10.7$ & $6.9 \pm 6.0$ \\
Alburnus alburnus & $12.9 \pm 11.4$ & $17.9 \pm 14.3$ & $19.9 \pm 17.4$ & $27.1 \pm 16.5$ \\
\hline
\end{tabular}

Data presented are results of IsoSource model (IsoM) (mean \pm standard deviation); Fish size categories: $\mathrm{S}=$ small; $\mathrm{M}=$ medium.

\footnotetext{
* Pūtys Ž. 2012. Didžiojo kormorano Phalacrocorax carbo sinensis mityba ir poveikis žuvų populiacijoms bei jų bendrijai Kuršiu marių eutrofinejje ekosistemoje. [Great cormorant Phalacrocorax carbo sinensis diet and its effect on fish populations and their community in the eutrophic Curonian Lagoon ecosystem.] Doctoral thesis. Vilnius University, Vilnius, Lithuania. [In Lithuanian.]
} 
Round goby is considered a benthic feeder, preying mainly on molluscs (especially Dreissena polymorpha), followed by crustaceans and other benthic animals (Ray and Corkum 1997, Barton et al. 2005, Karlson et al. 2007, Raby et al. 2010, Azour 2011). Performed gut content analysis revealed chironomids as the dominant prey in 2009 , which contrasted to individuals dissected in 2007 when zebra mussels were the prevailing food item (Fig. 5.). Similar results were reported by Barton et al. (2005) from Lake Erie in North America. They concluded that the diet of round goby has somewhat shifted in response to the decline in abundance of mussels in the littoral zone of the lake. Apparently, round goby diet depends on natural variation of prey availability in the environment as it was also concluded by Skóra and Rzeznik (2001) and Barton et al. (2005). However, any information about zebra mussel decline in the littoral part of the Curonian Lagoon is absent, thus such a pattern cannot be the reason for zebra mussel decline in the gut content of round goby in 2009 compared to 2007.

It should be acknowledged that stomach contents might be affected by variation in the retention time of different prey organisms (Fange and Grove 1979). The share of zebra mussel in round goby diet occasionally may be overestimated because mussel shells are indigestible and therefore are more easily identified in stomach content than soft-bodied prey (Brush et al. 2012).

Gut content represents only a recent "snapshot" of the actual diet and indicates only what has actually been ingested rather than assimilated. Meanwhile, stable nitrogen and carbon isotopes analysis reveals the diet in a year perspective (Gearing 1991, Hobson 1999). As shown by the SIA, round goby relied on ${ }^{13} \mathrm{C}$-enriched but not on ${ }^{13} \mathrm{C}$-depleted carbon source typical for zebra mussel. However, there was a significant correlation between the $\delta^{13} \mathrm{C}$ values and the body length in round gobies (Fig. 4). Larger individuals had lower values of $\delta^{13} \mathrm{C}$ than juveniles. As zebra mussels are depleted in $\delta^{13} \mathrm{C}$ compared to other putative prey such as amphipods and chironomids in the Curonian Lagoon (Lesutiene unpublished*), the observed pattern may indicate an ontogenetic change in dietary or feeding habitat preferences. The shift in $\delta^{13} \mathrm{C}$ with the increasing length of round goby was also reported from Lake Erie, North America (Barton et al. 2005). Previous studies in the Curonian Lagoon showed that during the first year of life Neogobius melanostomus individuals rely on chironomid larvae, ostracods, and amphipods, while during the second year and especially the third year their preferences shift to zebra mussels (Rakauskas et al. 2008). Presumably smaller gobies consume less zebra mussels because they lack the strength in their pharyngeal teeth to crush the shells (Brush et al. 2012). The $\delta^{15} \mathrm{~N}$ values of round goby changed little with body size suggesting that round goby did not shift to a more predatory diet. Consequently, round goby in the lagoon can be considered a generalist benthic feeder with ontogenetically increasing proportion of zebra mussels in the diet.

Isotopic niche of round goby was collated with that of the other resident fish species to reveal with which fish

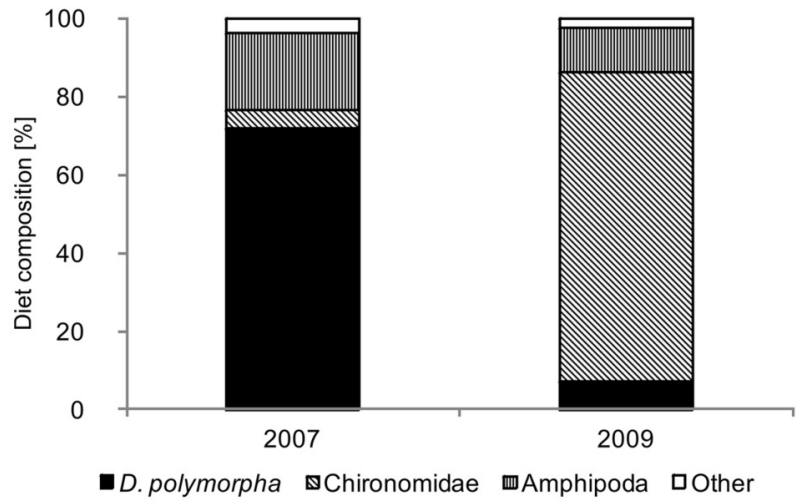

Fig. 5. Diet composition of $1+$ and $2+$ age round goby, Neogobius melanostomus, from the Curonian Lagoon revealed by gut content analysis in 2007 (Rakauskas et al. 2008) and in 2009 (presently reported study)

competition for food resources is most probable. Our initial hypothesis that the trophic niche of round goby in the lagoon would primarily overlap with that of other molluscivorous fish species such as roach or bream was not proved suggesting that these species may be assimilating spatially separated resources. The substantial spatial variation in the abundance of zebra mussel across the Curonian Lagoon is well documented (Zaiko unpublished ${ }^{* *}$ ). Surprisingly, there was not any overlap in the isotopic niches of round goby and large roach which has been reported to have zebra mussels as the main diet component (Kublickas 1959). In contrast, the closest isotopic niches were those of round goby and ruffe suggesting the largest dietary or habitat overlap. Such a pattern may have been expected as both round goby and ruffe documented to have similar habitat preferences (Bauer et al. 2007). Although ruffe is considered to rely mainly on chironomids, it has been assessed that the diet composition of this species in the Curonian Lagoon vary seasonally, and molluscs can comprise up to $15 \%$ of the species diet (Titova unpublished ${ }^{* * *}$ ). The SIA showed that $\delta^{13} \mathrm{C}$ values of round goby also overlapped with those of vimba bream. However the latter overlapping $\delta^{13} \mathrm{C}$ signatures may not necessary indicate consumption of the similar carbon sources. The vimba bream is a migratory fish species which mostly resides in the Baltic Sea and migrates to rivers for spawning (Repečka 2003), therefore its mean $\delta^{13} \mathrm{C}$ values can be derived from ${ }^{13} \mathrm{C}$-enriched marine sources.

Although the expansion of round goby in the Curonian Lagoon is still ongoing, some predictions of long-term consequences of this invasion could be made. Firstly, the abundance of round goby seems to be stabilized at relatively low densities in the northern part of the lagoon. Thus, it is unlikely that the species could dramatically change the composition of fish assemblage of the Curonian Lagoon and cause shifts in fishery yields in the future. However, the area colonised by round goby will expand until the species will establish in the entire lagoon. Secondly, it is likely that through resource and habitat competition, round goby may occasionally negatively

** Zaiko A. 2009. Habitat engineering role of the invasive bivalve Dreissena polymorpha (Pallas, 1771) in the boreal Lagoon Ecosystem. Doctoral thesis. Klaipeda University, Klaipeda, Lithuania.

** Titova J. 2007. Karšių (Abramis brama) ir pūgžlių (Gymnocephalus cernua) Kuršių marių šiaurès - rytų dalies (ties Ventès ragu) mitybiniai ypatumai. [Diet peculiarities of freshwater bream (Abramis brama) and ruffe (Gymnocephalus cernua) from the central part (near Vente Cape) of the Curonian Lagoon.] Master degree thesis. Vilnius University, Vilnius, Lithuania. [In Lithuanian.]
} 
impact other native benthivorous fish species, especially ruffe, in habitats where the newcomer will attain high densities. Finally, round goby population expansion and increase will definitely cause further alterations in the diet of top predators. Impacts on the diet of top predators are already seen. For the first time, round goby was recorded in great cormorant pellets in 2007 at relatively low proportion $(0.6 \%$ by number and $0.3 \%$ by weight) (Pūtys and Zarankaite 2010). Recently, in 2010, the contribution of round goby to the cormorant diet has substantially increased and was estimated at $3 \%$ by number and $9 \%$ by weight (Pūtys unpublished*). This study suggests the share of round goby in the diet of great cormorant at $12 \%$. Further round goby population increase in the lagoon could make the species an important prey for the great cormorant and the grey heron, and subsequently may raise the abundance of these piscivorous birds. The increase in the abundance of overwintering great cormorants in the Gulf of Gdańsk has been considered to be related to round goby invasion, and the invader has been reported to comprise about $70 \%$ of great cormorant diet (Bzoma and Meissner 2005). A similar change has been also observed in the diet of the double-crested cormorant, Phalacrocorax auritus, in the region of the Great Lakes in North America, where round goby was introduced during the last decade of the 20th century (Johnson and McCullough 2008, Bur et al. unpublished). It has been suggested that the rapid expansion of round goby had influenced grey heron and affected both the diet and the number of birds feeding and breeding in the vicinity of Puck Gulf (Jakubas 2004). Also, it should not be excluded that, being effective predators, piscivorous birds may exert regulatory impact on the population of round goby in the Curonian Lagoon, and that aspect definitely require further examination.

In summary, this prolonged study traced population expansion and abundance of an invasive fish species, round goby, in the Curonian Lagoon, and assessed its trophic role in the invaded ecosystem. Our data indicate an increase of round goby distribution, while its abundance tended to decline in the northern part of the lagoon during the last years suggesting species naturalisation. The feeding flexibility, i.e., the ability to consume various food items, of round goby, together with its tolerance to a wide range of ecological conditions and prolific reproduction suggest that this invader is likely to persist and become a resident fish species in the lagoon. Given round goby's potential for negative impacts on ecosystem function (as a result of competition with native benthivorous fish) as well as possible positive impacts on native piscivorous fish and birds (as a result of availability of a new food source), the role of the invader in the food web of the lagoon presumably will increase in the future. Certainly, because of the invasion and expansion of round goby, the ecosystem of the Curonian Lagoon is currently undergoing changes which final outcome is of scientific and applied interest.

\section{ACKNOWLEDGEMENTS}

This work, SIA and data analysis in particular, was supported by the Research Council of Lithuania, Project No. LEK-10/2012. We are especially grateful to Joseph R. Laroza (University of California) and Eglè Šidagytė (Nature Research Centre, Lithuania) for linguistic improvement of the manuscript.

\section{REFERENCES}

Almqvist G., Strandmark A.K., Appelberg M. 2010. Has the invasive round goby caused new links in Baltic food webs? Environmental Biology of Fishes 89 (1): 79-93. DOI: $10.1007 / \mathrm{s} 10641-010-9692-\mathrm{z}$

Anonymous 2005. Millennium ecosystem assessment. Ecosystem and human well-being: biodiversity synthesis. World Resources Institute, Washington, DC, USA.

Azour F. 2011. Fødebiologi hos den sortmundede kutling Neogobius melanostomus i danske farvande. [Feeding ecology of the round goby Neogobius melanostomus in Danish waters.] Bachelorprojekt [BSc Thesis.] University of Copenhagen. [In Danish.] http://snm.ku.dk/forskning/ projekter/fiskeatlas/billeder/Sortmundet_kutlings_f_debiolo gi_i_DK.pdf [Accessed on 18 March 2013.]

Bacevičius E. 2003. Pastabos apie Baltijos jūros ir Kuršių marių naujakurị - grundalą rubuilic. [Notes on round goby, a newcomer in the Baltic Sea and the Curonian Lagoon.] Žurnalas apie gamtą 3: 38-40. [In Lithuanian.]

Barton D.R., Johnson R.A., Campbell L., Petruniak J. Patterson M. 2005. Effects of round gobies (Neogobius melanostomus) on dreissenid mussels and other invertebrates in eastern Lake Erie, 2002-2004. Journal of Great Lakes Research 31 (Suppl. 2): 252-261. DOI: 10.1016/s0380-1330(05)70318-x

Bauer C.R., Bobeldyk A.M., Lamberti G.A. 2007. Predicting habitat use and trophic interactions of Eurasian ruffe, round gobies, and zebra mussels in nearshore areas of the Great Lakes. Biological invasions 9 (6): 667-678. DOI: $10.1007 / \mathrm{s} 10530-006-9067-8$

Bănaru D., Harmelin-Vivien M. 2009. Feeding behaviour of Black Sea bottom fishes: did it change over time? Acta Oecologica 35 (6): 769-777. DOI: 10.1016/j.actao.2009.08.003

Berg L.S. 1949. Ryby presnyh vod SSSR i sopredel'nyh stran. [Freshwater fishes of the USSR and adjacent countries.] Zoological Institute of the Academy of Sciences of the USSR, Leningrad, USSR. [In Russian.]

Björklund M., Almqvist G. 2010. Rapid spatial genetic differentiation in an invasive species, the round goby Neogobius melanostomus in the Baltic Sea. Biological Invasions 12 (8): 2609-2618. DOI: 10.1007/s10530-009-9669-z

Borowski W. 1999. Babka bycza w Zalewie Wiślanym. [Round goby in the Vistula Lagoon.] Magazyn Przemysłu Rybnego 4 (12): 39. [In Polish.]

Brush J.M., Fisk A.T., Hussey N.E., Johnson T.B. 2012. Spatial and seasonal variability in the diet of round goby (Neogobius melanostomus): stable isotopes indicate that stomach contents overestimate the importance of dreissenids. Canadian Journal of Fisheries and Aquatic Science 69 (3): 573-586. DOI: 10.1139/f2012-001

\footnotetext{
${ }^{*}$ See footnote on page 103 .
} 
Bzoma S. 1998. The contribution of round goby (Neogobius melanostomus Pallas, 1811) to the food supply of cormorants (Phalacorocorax carbo Linnaeus, 1758) feeding in the Puck Bay. Bulletin of the Sea Fisheries Institute 2: 39-48.

Bzoma S., Meissner W. 2005. Some results of long-term counts of water birds wintering in the western part of the Gulf of Gdansk (Poland) with special emphasis on the increase in the number of Cormorants Phalacrocorax carbo. Acta Zoologica Lituanica 15 (3): 105-108.

Caut S., Angulo E., Courchamp F. 2009. Variation in discrimination factors $\left(\delta^{15} \mathrm{~N}\right.$ and $\left.\delta^{13} \mathrm{C}\right)$ : the effect of diet isotopic values and applications for diet reconstruction. Journal of Applied Ecology 46 (2): 443-453. DOI: 10.1111/j.13652664.2009.01620.x

Charlebois P.M., Marsden J.E., Goettel R.G., Wolfe R.K., Jude D.J., Rudnicka S. 1997. The round goby, Neogobius melanostomus (Pallas), a review of European and North American literature with notes from the round goby conference, Chicago, 1996. Illinois Natural History Survey Lake Michigan Biological Station Zion, Il, USA. Aquatic Ecology Technical Report 96/10.

Chotkowski M.A., Marsden J.E. 1999. Round goby and mottled sculpin predation on lake trout eggs and fry: Field predictions from laboratory experiments. Journal of Great Lakes Research 25 (1): 26-35. DOI: 10.1016/S03801330(99)70714-8

Corkum L.D., Sapota M.R., Skora K.E. 2004. The round goby, Neogobius melanostomus, a fish invader on both sides of the Atlantic Ocean. Biological Invasions 6 (2): 173-181. DOI: 10.1023/B:BINV.0000022136.43502.db

Czugala A., Woźniczka A. 2010. The River Odra estuaryanother Baltic Sea area colonized by the round goby Neogobius melanostomus Pallas, 1811. Aquatic Invasions 5 (Suppl. 1): S61-S65. DOI: 10.3391/ai.2010.5.S1.014

DeNiro M.J., Epstein S. 1977. Mechanism of carbon isotope fractionation associated with lipid synthesis. Science 197 (4300): 261-263. DOI: 10.1126/science.327543

Fange R., Grove D. 1979. Digestion. Pp. 161-220. In: Hoar W.S., Randall D.J., Brett J.R. (eds.) Fish physiology. Vol. 8. Academic Press, New York, USA.

French J.R.P. III, Jude D.J. 2001. Diets and diet overlap of nonindigenous gobies and small benthic native fishes coinhabiting the St. Clair River, Michigan. Journal of Great Lakes Research 27 (3): 300-311. DOI: 10.1016/s03801330(01)70645-4

Fry B. 2006. Isotope notation and measurement. Pp. 21-35. In: Fry B. (eds.) Stable isotope ecology. Springer Science + Business Media LCC, New York, USA.

Gasiūnaitė Z.R., Daunys D., Olenin S., Razinkovas A. 2008. The Curonian Lagoon. Pp. 197-215. In: Schiewer U. (ed) Ecology of Baltic coastal waters. Ecological Studies 197. Springer-Verlag, Berlin Heidelberg.

Gearing J.N. 1991. The study of diet and trophic relationships through natural abundance ${ }^{13}$ C. Pp. $201-218$. In: Coleman D.C., Fry B. (eds.) Carbon isotope techniques. Academic Press, San Diego.

Hensler S.R., Jude D.J., He J. 2008. Burbot growth and diets in Lakes Michigan and Huron: an ongoing shift from native species to round gobies. American Fisheries Society Symposium 59: 91-107.

Hjelm J., Persson L., Christensen B. 2000. Growth, morphological variation and ontogenetic niche shifts in perch (Perca fluviatilis) in relation to resource availability. Oecologia 122 (2): 190-199. DOI: 10.1007/PL00008846

Hjelm J., van de Weerd G.H, Sibbing F.A. 2003. Functional link between foraging performance, functional morphology, and diet shift in roach (Rutilus rutilus). Canadian Journal of Fisheries and Aquatic Science 60 (6): 700-709. DOI: 10.1139/f03-058

Hobson K.A. 1999. Tracing origins and migration of wildlife using stable isotopes: a review. Oecologia 120 (3): 314-326. DOI: $10.1007 / \mathrm{s} 004420050865$

Horppila J., Ruuhijärvi J., Rask M., Karppinen C., Nyberg K., Olin M. 2000. Seasonal changes in the diets and relative abundances of perch and roach in the littoral and pelagic zones of a large lake. Journal of Fish Biology 56 (1): 51-72. DOI: 10.1111/j.1095-8649.2000.tb02086.x

Jacobs G.R., Madenjian C.P., Bunnell D.B., Holuszko J.D. 2010. Diet of lake trout and burbot in northern Lake Michigan during spring: Evidence of ecological interaction. Journal of Great Lakes Research 36 (2): 312-317. DOI: 10.1016/j.jglr.2010.02.007

Jakubas D. 2004. The response of the grey heron to a rapid increase of the round goby. Waterbirds 27 (3): 304-307. DOI: $10.1675 / 1524-4695(2004) 027[0304$ :TROTGH]2.0. $\mathrm{CO} ; 2$

Jaschinski S., Brepohl D.C., Sommer U. 2011. The trophic importance of epiphytic algae in a freshwater macrophyte system (Potamogeton perfoliatus L.): stable isotope and fatty acid analyses. Aquatic Sciences 73 (1): 91-101. DOI: 10.1007/s00027-010-0163-6

Johnson J.H., McCullough R.D. 2008. Diet composition and fish consumption of double-crested cormorants from the Pigeon and Snake island colony of eastern lake Ontario in 2007. Section 16: 1-9. NYSDEC Lake Ontario Annual report.

Johnson T.B., Bunnell D.B., Knight C.T. 2005. A potential new energy pathway in Central Lake Erie: the round goby connection. Journal of Great Lakes Research 31 (Suppl. 2): 238-225. DOI: 10.1016/S0380-1330(05)70317-8

Jude D.J., Janssen J. Crawford G. 1995. Ecology, distribution, and impact of the newly introduced round (and) tubenose gobies on the biota of the St. Clair and Detroit Rivers. Pp. 447-460. In: Munawar M., Edsall T., Leach J. (eds.) The Lake Huron ecosystem: ecology, fisheries and management. SPB Academic Publishing, Amsterdam, the Netherlands.

Karlson A.M.L., Almqvist G., Skóra K.E., Appelberg M. 2007. Indications of competition between non indigenous round goby and native flounder in the Baltic Sea. ICES Journal of Marine Science 64 (3): 479-486. Doi: 10.1093/icesjms/fs1049

Kipp R., Hébert I., Lacharité M., Ricciardi A. 2012. Impacts of predation by the Eurasian round goby (Neogobius melanostomus) on molluscs in the upper St. Lawrence River. Journal of Great Lakes Research 38 (1): 78-89. DOI: 10.1016/j.jglr.2011.11.012 
Kornis M.S., Mercado-Silva N., Vander Zanden M.J. 2012. Twenty years of invasion: a review of round goby Neogobius melanostomus biology, spread and ecological implications. Journal of Fish Biology 80 (2): 235-285. DOI: $10.1111 / j .1095-8649.2011 .03157 . x$

Kovtun I.F., Nekrasova M.Â., Revina N.I. 1974. O piŝevyh racjonah i ispol'zovanii kormovoj bazy byčkom-kruglâkom $\mathrm{v}$ Azovskom more. [On the diet and utilization of the food base by round goby in the Azov Sea.] Zoologičeskij Žurnal [Zoologicheskiy Zhurnal] 53 (5): 728-736. [In Russian].

Kublickas A. 1959. Pitanie bentosojadnyh ryb Zaliva Kuršju mares. [Nourishment of bentic feeder fish in Curonian Lagoon.] Pp. 551. In: Jankevičius K. (ed.) Kuršju mares. [Curonian Lagoon.] Pjargale, Vilnjus. [In Russian.]

Layman C.A., Arrington D.A., Montaña C.G., Post D.M. 2007. Can stable isotope ratios provide for community-wide measures of trophic structure? Ecology 88 (1): 42-48. DOI: 10.1890/0012-9658(2007)88[42:CSIRPF]2.0.CO;2

Lederer A., Massart J., Janssen J. 2006. Impact of round gobies (Neogobius melanostomus) on dreissenids (Dreissena polymorpha and Dreissena bugensis) and the associated macroinvertebrate community across an invasion front. Journal of Great Lakes Research 32 (1): 1-10. DOI: 10.3394/0380-1330(2006)32[1:IORGNM]2.0.CO;2

Ložys L. 2004. The growth of pikeperch (Sander lucioperca L.) and perch (Perca fluviatilis L.) under different water temperature and salinity conditions in the Curonian Lagoon and Lithuanian coastal waters of the Baltic Sea. Hydrobiologia 514 (1-3): 105-113. DOI: 10.1023/B:hydr.0000018211.26378.b9

Madenjian C.P., Stapanian M.A., Witzel L.D., Einhouse D.W., Pothoven S.A., Whitford H.L. 2011. Evidence for predatory control of the invasive round goby. Biological Invasions 13 (4): 987-1002. DOI: 10.1007/s10530-010-9884-7

McCutchan J.H.jr., Lewis W.M.jr., Kendall C., McGrath C.C. 2003. Variation in trophic shift for stable isotope ratios of carbon, nitrogen, and sulfur. Oikos 102 (2): 378-390. DOI: $10.1034 / j .1600-0706.2003 .12098 . x$

Ojaveer H. 2006. The round goby Neogobius melanostomus is colonising the NE Baltic Sea. Aquatic Invasions 1 (1): 44-45. DOI: 10.3391/ai.2006.1.1.11

Phillips D.L., Gregg J.W. 2003. Source partitioning using stable isotopes: coping with too many sources. Oecologia 136 (2): 261-269. DOI: 10.1007/s00442-003-1218-3

Pląchocki D., Kobak J., Kakareko T. 2010. First report on the importance of alien gobiids in the diet of native piscivorous fishes in the lower Vistula River (Poland). Oceanological and Hydrobiological Studies 41(2): 83-89. DOI: 10.2478/s13545-012-0020-4

Post D.M. 2002. Using stable isotopes to estimate trophic position: models, methods, and assumptions. Ecology 83 (3): 703-718.DOI: 10.1890/00129658(2002)083[0703:USITE] 2.0.CO;2

Pūtys Ž., Zarankaitè J. 2010. Diet of the Great Cormorant (Phalacrocorax carbo sinensis) at the Juodkrante colony, Lithuania. Acta Zoologica Lituanica 20 (3): 179-189.

Quevedo M., Svanbäck R., Eklöv P. 2009. Intrapopulation niche partitioning in a generalist predator limits food web connectivity. Ecology 90 (8): 2263-2274. DOI: 10.1890/07-1580.1
Raby G.D., Gutowsky L.F.G., Fox M.G. 2010. Diet composition and consumption rate in round goby (Neogobius melanostomus) in its expansion phase in the Trent River, Ontario. Environmental Biology of Fishes 89 (2): 143-150. DOI: $10.1007 / \mathrm{s} 10641-010-9705-y$

Ray W.J., Corkum L.D. 1997. Predation of zebra mussels by round gobies, Neogobius melanostomus. Environmental Biology of Fishes 50 (3): 267-273. DOI: 10.1023/ A: 1007379220052

Ray W.J., Corkum L.D. 2001. Habitat and site affinity of the round goby. Journal of Great Lakes Research 27 (3): 329-334. DOI: 10.1016/S0380-1330(01)70648-X

Rakauskas V., Bacevičius E., Pūtys Ž., Ložys L., Arbačiauskas K. 2008. Expansion, feeding and parasites of the round goby, Neogobius melanostomus (Pallas, 1811), a recent invader in the Curonian Lagoon, Lithuania. Acta Zoologica Lituanica 18 (3): 180-190.

Repečka R. 2003. The species composition of the ichthyofauna in the Lithuanian economic zone of the Baltic Sea and the Curonian lagoon and its changes in recent years. Acta Zoologica Lituanica 13 (2): 149-157.

Reise K., Olenin S., Thieltges D.W. 2006. Are aliens threatening European aquatic coastal ecosystems? Helgoland Marine Research 60 (2): 77-83. DOI: 10.1007/s10152-0060024-9

Reyjol R., Brodeur P., Mailhot Y., Mingelbier M., Dumont P. 2010. Do native predators feed on non-native prey? The case of round goby in a fluvial piscivorous fish assemblage. Journal of Great Lakes Research 36 (4): 618-624. DOI: 10.1016/j.jglr.2010.09.006

Rolff C., Elmgren R. 2000. Use of riverine organic matter in plankton food webs of the Baltic Sea. Marine Ecology Progress Series 197: 81-101. DOI: 10.3354/meps197081

Sapota M.R., Skóra K.E. 2005. Spread of alien (non-indigenous) fish species Neogobius melanostomus in the Gulf of Gdansk (south Baltic). Biological Invasions 7 (2): 157-164. DOI: $10.1007 / \mathrm{s} 10530-004-9035-0$

Schmidt S.N., Olden J.D., Solomon C.T., Vander Zanden M.J. 2007. Quantitative approaches to the analysis of stable isotope food web data. Ecology 88 (11): 2793-2802. DOI: 10.1890/07-0121.1

Shpilev H., Ojaveer E. 2003. Round goby, Neogobius melanostomus (Pallas). Pp 336-337. In: Ojaveer E., Pihu E., Saat T. (eds.) Fishes of Estonia. Estonian Academy Publishers, Tallinn, Estonia.

Skora K.E., Rzeznik J. 2001. Observations on diet composition of Neogobius melanostomus Pallas 1811 (Gobiidae, Pisces) in the Gulf of Gdansk (Baltic Sea). Journal of Great Lakes Research 27 (3): 290-299. DOI: 10.1016/S03801330(01)70644-2

Skóra K.E., Stolarski J. 1993. New fish species in the Gulf of Gdańsk, Neogobius sp [cf. Neogobius melanostomus (Pallas 1811)]. Bulletin of the Sea Fisheries Institute 1 (128): 83-84.

Steinhart G.B., Marschall E.A., Stein R.A. 2004. Round goby predation on smallmouth bass offspring in nests during simulated catch-and-release angling. Transactions of the American Fisheries Society 133 (1): 121-131. DOI: $10.1577 / \mathrm{T} 03-020$ 
Svanbäck R., Eklöv P. 2002. Effects of habitat and food resources on morphology and ontogenetic growth trajectories in perch. Oecologia 131 (1): 61-70. DOI: $10.1007 / \mathrm{s} 00442-001-0861-9$

Svietovidov A.N. 1964. Fishes of the Black Sea. Moscow: Soviet Academy of Sciences. [In Russian].

van Beek G.C.W. 2006. The round goby Neogobius melanostomus first recorded in the Netherlands. Aquatic Invasions 1 (1): 42-43. DOI: 10.3391/ai.2006.1.1.10

Vander Zanden M.J., Casselman J.M., Rasmussen J.B. 1999. Stable isotope evidence for the food web consequences of species invasions in lakes. Nature 401 (6752): 464-467. DOI: $10.1038 / 46762$

Vanderploeg H.A., Nalepa T.F., Jude D.J., Mills E.L., Holeck K.T., Liebig J.R., Grigorovich I.A., Ojaveer H. 2002. Dispersal and emerging ecological impacts of Ponto-Caspian species in the Laurentian Great Lakes. Canadian Journal of Fisheries and Aquatic Sciences 59 (7): 1209-1228. DOI: 10.1139/f02-087

Weimer M.T., Keppner S.M. 2000. The round goby (Neogobius melanostomus) in Lake Erie. Great Lakes Research Review 5 (1): 19-24.

Wolfe R.K., Marsden J.E. 1998. Tagging methods for the round goby (Neogobius melanostomus). Journal of Great
Lakes Research 24 (3): 731-735. DOI: 10.1016/S03801330(98)70857-3

Zolubas T. 2003. Nauja invazinè žuvų rūšis Lietuvos vandenyse. [New invasive fish species in Lithuanian waters.] Jūra ir aplinka 2 (9): 52-56. [In Lithuanian.]

Žaromskis R. 1996. Vandenynai, Jūros, Estuarijos. [Oceans, Seas, Estuaries.] Debesija, Vilnius, Lithuania. [In Lithuanian.]

Žiliukas V. 2003. Assessment of the dynamics of main ecological parameters of the fish fry community in the coastal zone of the Curonian lagoon near Vente Cape. Acta Zoologica Lituanica 13 (2):167-175.

Žiliukienė V. 1998. Kuršių marių ichtioplanktonas. [Ichthyoplankton of the Curonian lagoon.] Žuvininkyste Lietuvoje 3 (1): 215-225. [In Lithuanian.]

Žydelis R., Kontautas A. 2008. Piscivorous birds as top predators and fishery competitors in the lagoon ecosystem. Hydrobiologia 611 (1): 45-54. DOI: 10.1007/s10750-0089460-7

Received: 6 September 2012

Accepted: 13 April 2013

Published electronically: 30 June 2013 